\title{
Болгарские конструкции с предикативным определением: в поисках прототипической модели
}

\author{
Е. Ю. ИВАНОВА \\ Кафедра славянской филологии, Санкт-Петербургский государственный университет, \\ Университетская наб., д. 11, RU-199034 Санкт-Петербург \\ E-mail: e.y.ivanova@spbu.ru
}

(Received: 23 March 2016; accepted: 17 June 2016)

\begin{abstract}
Constructions with depictive attributes representing a special kind of secondary predication have been the object of recent discussions within the formal and constructional frameworks. One of the key issues in understanding this phenomenon and the variants of its realization in various languages is the identification of its prototypical model. The present paper shows that in Bulgarian, the core construction with the subject-oriented depictive secondary predicate contains the verb of controlled action as the main predicate and a non-finite form of the verb of uncontrolled action. In this way, the search of the prototypical model is related to the feature "controllability/uncontrollability of action" discerned in the semantics of both main and secondary predication. Based on the suggested parameter, the other variety of the construction in question, the one with the object-oriented depictive secondary predicate, has a different organization not only in the syntactic but also in the semantic aspect. It is demonstrated that different semantic varieties of constructions with the depictive secondary predicate have different translations in Russian.
\end{abstract}

Keywords: Bulgarian, syntax, depictive, secondary predication, controllability of action

Конструкции с предикативным определением (далее ПО), или, в более новых терминах, депиктивные ${ }^{1}$ конструкции, всегда находились в зоне особого внимания лингвистов благодаря специфике синтаксической связи вторичной и основной предикации: предикативное определение, контролируясь подлежащим или дополнением - носителем признака из основной предикации, соотнесено в то же время и с основным предикатом, например:

рус. Он пришел устальмм /устальй; Мыз застали их целующимися.

болг. Наблюдаваме ни замислен 'Он наблюдал за нами в задумчивости /задумавшись', ${ }^{2}$ Намерих я заспала на леглото '(букв.) Я обнаружил ее уснувшей на кровати'.

Формально ориентированные концепции описывают подобные депиктивные конструкции (в разных языках) как нетривиальный пример вторич-

${ }^{1}$ Депиктивом (depictive, depictive secondary predicate) называется вторично приписываемый именной компонент в составе данной конструкции (см. SCHULTZE-BERNDT-HIMMELMANN 2004, HimmelmanN-Schultze-Berndt 2005), ср. и copredicate (Nichols 1978).

2 Приводимые русские переводческие соответствия не всегда могут отразить синтаксическую и семантическую специфику болгарского ПО (о способах перевода ПО на русский язык см. в разделе 4). 
ной предикации. Конструкции с депиктивами характеризуются как предложения, содержащие два предиката: один - основной, другой - второстепенный, выражающий действие, происходящее внутри временных рамок действия основного предиката. Главные теоретические принципы исследования депиктивных конструкций на широком типологическом фоне представлены в работе НimmelmanN-SCHULtZE-BeRndt 2005a, где уделяется много внимания не только синтаксическому устройству данных построений в разных языках, но и семантике входящих в них компонентов (об основных признаках деПиктивов см. также НЕВСКАЯ 2015: 85-86).

Внимание исследователей русского языка прежде всего сосредоточено на разграничении конструкций с творительным падежом и конструкций с формальным согласованием, ср.: Он пришел пьянымм и Он пришел пьяный. Этой проблеме посвящен не один десяток исследований: например, NichOLS 1978, Filip 2001, НикУНлАсси 1993, ЗЕЛьдович 2005 и др. (см. также обобщение и литературу: КУЗНЕЦОВА-РАХИЛИНА 2010, КУЗНЕЦОВА-РАХИЛИНА 2014). Соавторы последних упомянутых исследований Ю. Л. Кузнецова и Е. В. Рахилина анализируют предложения данного типа в терминах Грамматики конструкций. Их описание исходит из основного постулата этого подхода о том, что свойства конструкции задаются совокупностью ее элементов, а элементы конструкции взаимозависимы и интерпретируются во взаимодействии друг с другом. Общим значением для всех случаев употребления конструкции предлагается считать контраст между новым и каким-либо другим, «фоновым» признаком. Поиск прототипической модели приводит авторов к глаголам, имеющим валентность на признак с переменным значением, а именно к предложениям с глаголами оценочного восприятия действительности (например, Фельдшер казался равнодушныл), изменения состояния (Пока подливка не станет однородной) и их каузативными коррелятами (Это сделало ux знаменитылми). Эти конструкции и утверждаются авторами как исходные, прототипические депиктивные конструкции. Заметим, что при иных подходах эти предложения обычно не рассматриваются как содержащие депиктивы: для последних необходима комбинация двух предикативных признаков.

В болгарском языке, в отличие от русского, для конструкций с предикативным определением нерелевантны падежные различия, которые могли бы маркировать депиктивное употребление, и, что сейчас важнее для темы данной статьи, сфера употребления предикативного определения значительно шире, чем в русском: она охватывает те зоны вторичной предикации, которые в русском языке выражаются причастиями, деепричастиями, придаточными предложениями и предложными конструкциями состояния.

Заметим, что в большинстве исследований депиктивных конструкций основной анализ сосредоточен на изучении свойств прилагательных и их приспособленности к выражению вре́менного признака, то есть изучается их «депиктивный потенциал» (ср. обсуждение в HimMELMANN-SCHULTZE-BERNDT 2005b) приспособленности «стадиальных» и «индивидных» предикатов (т. е. stage-level and individual-level predicates) к функциям ПО. 
Для болгарского языка участие прилагательных в конструкциях с ПО является более редким, второстепенным способом частеречного выражения ПО. В качестве основной грамматической разновидности ПО для болгарского языка выступает построение с причастной формой (или отпричастным образованием) в роли «вторичного» сказуемого. Это позволяет исследовать пару «сказуемое - (от)причастное предикативное определение» в их соотнесенности и взаимообусловленности как две глагольные формы. Далее мы покажем, какова данная обусловленность, если за точку отсчета взять такой параметр, как признак «контролируемость /неконтролируемость», содержащийся в семантике финитной и нефинитной глагольных форм, входящих в состав конструкции с причастным ПО. Важной разновидностью ПО в болгарском языке является и придаточное предложение, однако оно используется только при «объектных» ПО (об этом см. далее).

Сначала обратимся к данным, накопленным болгарской лингвистикой при изучении конструкций с ПО.

\section{1. Предикативное определение как член предложения в болгарской лингвистике}

Предикативное определение (или «сказуемно определение») считается в большинстве грамматик болгарского языка второстепенным членом болгарского предложения (см., однако, ГСБКЕ 1983: 138). Отнесение именно к второстепенным членам основано на его синтаксической факультативности, поскольку ПО не является структурно обязательным': Той влезе 'Он вошел'. - Той влезе мрачен 'Он вошел мрачным'; Тя си отиде 'Она ушла'. - Тя си отиде доволна 'Она ушла довольная'; Видях го 'Я увидел его'. - Видях го весел и безгрижен 'Я увидел его веселым и беззаботным'.

При этом в структурно-семантических описаниях термин «сказуемно определение» до недавнего времени применялся не только к ПО как особому члену предложения, но и к определению в составе именного сказуемого как при глаголе $c b$, так и с фазисными, авторизующими и каузирующими связками: станал си по-добър 'ты стал добрее'; останах доволен 'я остался доволен'; изглежда мрачен 'он выглядит мрачным'; тази рокля те прави дебела 'это платье делает тебя толстой'. Для терминологического отграничения ПО от смежных форм в более новых работах именные части сказуемого получили название «предикатив», но выбор названия для ПО еще обсуждается, ср., например, предлагаемый П. Радевой термин «чрезсказуемно

\footnotetext{
${ }^{3}$ Отнесение ПО к второстепенным членам предложения осуществляется при абстрагировании от коммуникативной и смысловой значимости ПО, а она высока: сопровождая сказуемое, такое определение обычно перетягивает на себя коммуникативный фокус, ослабляя семантику основного предиката, и входит с ним вместе в рематическую группу. В традиционной русской лингвистике это считается достаточным основанием для признания ПО сложным сказуемым: Она вернулась уставшей.
} 
определение» (РАдЕВА 2005). Однако общепринятым пока остается только «сказуемно определение». В работах болгаристов, выполненных в русле теории управления и связывания, предикативные определения анализируются как «малки изречения» (Пенчев 1993: 73, КоеВА 2001: 61).

В болгаристике выделяются два вида ПО:

1. ПО к подлежащему («субъектное» ПО, иногда называемое «первым» ПО). Оно, будучи типичным депиктивом, приписывает неустойчивый, переменный признак участнику - субъекту основной предикации, согласуясь с ним, в случае своего формоизменения, по роду и числу, или, иначе говоря, контролируясь им: Той влезе усмихнат '(букв.) Он вошел улыбающийся'); Тя влезе усмихната; ${ }^{4}$ То [момичето] влезе усмихнато; Те влязоха усмихнати;

2. ПО к прямому дополнению («объектное» ПО, «второе» ПО) контролируется участником - объектом основной предикации (прямым дополнением): Кафето го обичам студено 'Кофе я люблю холодным'; Пия го топъл 'Я пью его теплым'; Видях го усмихнат '(букв.) Я увидел его улыбающимся'); Видях я усмихната; Видях го [момичето] усмихнато; Видях ги усмихнати.

Конструкции с объектным ПО при глаголах восприятия, как в последних примерах, для болгарского языка крайне характерны. Формальные концепции депиктивных конструкций обращают внимание на то, что синтаксическая связь в таких случаях несколько сложнее, поскольку происходит не только приписывание признака участнику - объекту основной предикации, но и все положение дел, обозначенное вторичной предикацией, предстает как объект восприятия (Видях [я усмихната] ' Я увидел [ее улыбающейся]'). Об особом («комплементативном») характере таких конструкций см., наприMep, VAN DER AUWERA-MALCHUKOV 2005, где они все же анализируются вместе с «классическими» депиктивными конструкциями ввиду их близости.

В редких случаях взятое вне контекста болгарское предложение с ПО не дает возможности определить, с которой из двух конструкций мы имеем дело, - субъектной или объектной. Так, предложение Тя я чакаше уморена может трактоваться как имеющее «субъектное» ПО '(букв.) Она ждала ее уставшая') или как имеющее «объектное» ПО '(букв.) Она ждала ее уставшей' ('ждала, что та вернется уставшей').

\section{2. Предикативное определение и другие члены предложения - способы идентификации}

ПО как член предложения вычленяется в болгарской фразе вполне отчетливо, хотя в некоторых случаях ПО могут быть омонимичны другим членам предложения. Критерии их разграничения хорошо разработаны в болгарской лингвистике, в том числе с привлечением различных доказательных процедур (см. ПеНчев 1993, ПеНЧев 1998, ЛАЗАРОвА 2001, БъРКАЛОВА 2001, КоевА 2001).

\footnotetext{
${ }^{4}$ В связи с «нулевоподлежащностью» болгарского языка чаще встречается «закадровое» (БЪРКАЛОВА 2001: 23) подлежащее: Влезе усмихнат/усмихната.
} 
Отличие ПО-существительных от дополнения (аргумента глагола) активно обсуждается в болгарской лингвистической литературе в связи с проблемой примыкания. При переходном глаголе и дополнение, и ПО-существительное связаны с глаголом беспредложно, но их синтаксические функции в предложении различны.

Приведем основные морфологические процедуры идентификации этих двух явлений:

1. Дополнение при переходном глаголе (см., например, существительное в словосочетаниях типа отварям прозорец, вземам книга, пииа писма, давам интервю) имеет следующие свойства:

а) оно субституируется личным местоимением в винительном падеже: отварям го, вземам я, пиша ги, давам го;

б) допускает пассивизацию: отварям прозореи - прозорецът е отворен; вземам книга - книгата е взета; пиша писма - писмата са писани; давам интервю - интервюто е дадено;

в) существительное-дополнение может получать определенный артикль: отварям прозорециа, вземам книгата, пиша писмата.

2. ПО (существительное в словосочетаниях типа заминавам доброволец, отивам войник):

а) субституируется местоимением такъв (или его формами): заминавам (като) такъв, отивам (като) такъв;

б) не подлежит пассивизации: *заминат е доброволещ;

в) постановка определенного артикля при ПО невозможна: *заминавам доброволецът;

г) ПО к дополнению невозможно без эксплицитного прямого дополнения: направиха го герой - *направиха герой (ЛАЗАРОВА 2001: 9-10; ср. БъРКАлОВА 2001, КОЕВА 2001).

Общие черты ПО и именного компонента составного сказуемого, включая и их одинаковые реакции на многие тесты, приведенные выше, показаны как в генеративистских концепциях на болгарском материале (см. работы Й. Пенчева, Св. Коевой), так и в исследованиях в духе Грамматики конструкций (ср. КузнЕцОВА-РАХИлинА 2010). Традиционная лингвистика при выявлении отличий ПО от именного компонента составного сказуемого опирается прежде всего на семантическую достаточность сказуемого при ПО и способность основного глагола формировать самостоятельную предикацию. Предложение с субъектным ПО разворачивается в две самостоятельных предикации с одинаковой временной отнесенностью: Той се върна мълчалив (=Той се върна. Той беше мълчалив), ср. с именным сказуемым Той стана мълчалив (*Tой стана. Той беше мълчалив). В современных исследованиях депиктивных конструкций отличие этих двух предложений объясняется тем, что определительный компонент (ПО) в первом предложении не является комплементом основного предиката върна се, в то время как во втором примере глагол стана имеет валентность на признак. 
По сравнению с атрибутом имени, болгарское ПО преимущественно постпозитивно к глаголу, обычно входит в рему и имеет нулевую артиклевую маркированность, например, Премръзналите (атрибут) пътници се прибраха по домовете си и Пътниците се прибраха по домовете си премръзнали (ПО) (РАДЕВА 2005: 434).

ПО и наречное обстоятельство могут формально совпадать, когда предикативное определение выражено формой среднего рода, например, Детето чакаше майка си радостно. При этом ПО допускает изменение по роду или числу (Тя чакаше майка си радостна. - Те чакаха майка си радостни), а наречие - нет. Из других подсказок упомянем порядок слов: в отличие от ПО, обстоятельство может занимать место перед глаголом: Тя радостно чакаше майка си.

\section{3. Морфологические типы предикативного определения}

1. Подавляющая часть ПО в болгарском языке выражена причастиями (страдательными и действительными причастиями прошедшего времени), в том числе такими, которые в современном языке перешли в разряд прилагательных: Той я наблюдаваше замислен; Влезе запъхтян. В значительно меньшей степени ПО выражаются прилагательными: Тя вървеше боса и гологлава.

2. Незначительная часть ПО выражена существительными: Той замина доброволец; Отива войник, или предложной группой: Знаех ги като деца.

3. Возможны в качестве ПО числительные, прежде всего порядковые: Влезе пьрва; Пристигнахме втори. Статус количественных числительных как ПО (Той си тръгна сам, а се върнаха двамата) не признается многими лингвистами.

4. В качестве ПО способны функционировать лишь единичные местоимения. Так, указательное такъв является субститутом прилагательных и причастий: Никога не съм го виждала такъв. Легко занимают место ПО определительные местоимения сам и ияял: ${ }^{5}$ Можеш ли да го направии сама?; Изяде го цяло.

\section{4. Семантика ПО}

Семантике ПО в болгарской лингвистике уделяют намного меньше внимания - возможно потому, что, если принимать во внимание все морфологические типы ПО, разнообразие их значений вряд ли можно сформулировать более конкретизированно, чем приписывание сопутствующего действию

\footnotetext{
${ }^{5}$ Возможность трактовать эти «плавающие определители» как ПО подвергается сомнению: в русском языке они не способны выступать в творительном падеже в качестве присказуемостных имен: видел их самих // обоих// всех// одних (*самими, *обоими, *всеми, *одними) (ТЕСТЕЛЕЦ 2001: 296-297).
} 
признака, причем признака в самом широком значении. ${ }^{6}$ Так, в примерах с числительными определители привносят обстоятельственный оттенок действия (пристигнах първа 'я прибыла первой'). Конструкции с существительными сообщают об обретении субъектом нового статуса: избраха го за председател 'его выбрали председателем', отиде войник '(букв.) ушел солдатом'/ 'в армию', или пребывании в этом статусе: работя като инженер 'работать инженером'. В единичных случаях ПО с существительными обозначают состояние, в котором лицо находится во время осуществления действия: той се завърна сиромах 'он вернулся нищим'. Придаточные предложения приписывают объекту динамический признак, обычно процессный: Видях я как влиза в двора 'Я увидел ее входящей (букв. как входит) во двор'.

Прилагательные и причастия в конструкции с ПО всегда обозначают временный признак. Конструкции с причастиями и отпричастными образованиями как наиболее частотным, регулярным грамматическим выражением ПО предстают как главная форма выражения депиктивного значения в болгарском языке.

Проанализируем две синтаксические модели конструкций с ПО (к подлежащему и к дополнению). Здесь будут показаны и соответствия между семантическими типами ПО в болгарском языке и их функциональными эквивалентами в русском. Из нашего рассмотрения будут исключены некоторые более частные типы предикативных определений, указывающие на «фазы» (phase, см. HimmelmanN-Schultze-Berndt 2005a) или «статусы» (function), например, Знаех го още като дете; Пристигнах първа; Ожених се млад; Ожениха ги млади.

\section{1. Конструкция с ПО к подлежащему (с «субъектным» ПО)}

В конструкции с субъектным ПО (субъектным депиктивом) эксплицитно и неопосредованно реализуется синтаксическая связь субъектного актанта с двумя предикативными признаками - основным и вторично приписанным. Основное значение депиктива, выраженного причастием или «стадиальным» прилагательным, - состояние субъекта во время совершения им действия, обозначенного в главной предикации.

Такая семантика требует постановки в позицию депиктива соответствующей лексики. Это причастия, образованные преимущественно от глаголов неконтролируемых действий (загрижен 'озабоченный', отмалял 'ослабевший', навъсен 'нахмурившийся', задъхан 'запыхавшийся'), а также неглагольные предикаты со значением актуального состояния (здрав 'здоровый',

\footnotetext{
${ }^{6}$ Формулировки общего значения депиктивных конструкций из более новых исследований тоже не содержат семантической конкретизации признака, ср.: «субъект либо объект в момент, описываемый предикатом $\mathrm{V}$, характеризуется некоторым вре́менным значением неустойчивого признака» (КУзНЕцОВА-РАХИЛИНА 2010: 167).

${ }^{7}$ При этом подлежащего может и не быть, но субъект должен предполагаться (РАдЕВА 2005: 434).
} 
гневен 'разгневанный', мрачен 'мрачный', зъл 'злой', мълчалив 'молчаливый', гузен 'виноватый' и т. д.).

Заметим, что анализ депиктивного компонента в большинстве исследований исходит из конструкций не с причастиями, а прилагательными (см. показательный разбор начальных примеров в статьях из сборника HIMMELMANN-SchUltZE-BERndT 2005a). Активно обсуждается вопрос о семантических типах прилагательных, способных участвовать в депиктивных конструкциях. Так, для тестирования прилагательных как «стадиальных», наиболее приспособленных для участия в депиктивной конструкции, предлагается языковой тест на введение временных конкретизаторов еще не и уже не (HINTERHOELZL 2001), который дает положительный результат для депиктивно употребленных прилагательных: Яблоки сорвали ещзе не зрельми.

Наш болгарский материал, однако, показывает, что в болгарском языке категорически преобладающей, наиболее контекстно независимой, выражающей значение исследуемой конструкции в минимальном лексическом и контекстном окружении, является причастная форма предикативного определения. Использование причастий, как правило, ослабивших свои динамические характеристики, делает излишним введение в депиктивные конструкции любых лексем, подсказывающих их «стадиальное» значение, т. е. значение временного, эпизодического, неустойчивого признака.

Наиболее частотные из лексем, выступающих в роли ПО, хорошо известны, см. их список по версии ГСБКЕ 1983: 138, в основном, представляющий причастия (в том числе перешедшие в разряд прилагательных): безгрижен, безмълвен, безучастен, благ, бледен, бос, волен, гологлав, грохнал, доволен, екзалтиран, ентусиазиран, загледан, загрижен, замислен, засмян, захласнат, зашеметен, зяпнал, изморен, изненадан, изнурен, изоставен, изплашен, изправен, изтерзан, изтощен, изумен, легнал, ликуващ, любопитен, мълчалив, наведен, наежен, настръхнал, ненаживян, ненаситен, нервиран, несигурен, неспокоен, неуморим, неутешим, обезверен, обезпокоен, обезумял, озадачен, окаян, омагьосан, онемял, освирепял, отпаднал, очарован, печален, плах, подпухнал, посърнал, пребледнял, преуморен, прехласнат, приведен, радостен, развълнуван, раздразнен, разлютен, разсеян, разсърден, разтревожен, разчувстван, разярен, самотен, свит, сдържан, седнал, слисан, сломен, смаян, смирен, спокоен, стреснат, съкрушен, сърдит, угнетен, угрижен, удивен, ужасен, умислен, умърлушен (а сейчас чаще - омърлушен), унесен, усмихнат, ухилен, учуден, хубав, щзастлив, ядосан и др.

Среди конструкций с причастным ПО с общим значением 'действие субъекта в некотором состоянии, актуальном на момент этого действия’ выделяются две группы употреблений. В одних предложениях (их большинство) указанное значение ничем не осложнено, действие и состояние представлены как независимые друг от друга явления: Влезе задъхан 'Вошел запыхавшись (букв. запыхавшийся)'. В других предложениях имеется причинноследственная связь между действием и состоянием: Тя се изчерви засрамена 'Она покраснела, застыдившись (букв. застыдившаяся)'. 
Различие этих групп, как представляется, определяется признаком контролируемости действия ${ }^{8}$ основного глагола.

а) Можно предположить, что сказуемое, выраженное глаголом контролируемого действия, и ПО от глагола неконтролируемого действия (или неглагольный предикат состояния), т. е. V (+ contr.)/Dep (- contr.), образуют центральную, прототипическую конструкцию с субъектным ПО. Действительно, такое сочетание компонентов, разных по контролируемости, однозначно обеспечивает наиболее характерную семантику конструкции - это сообщение о действии лица, находящегося в том или ином состоянии:

Майка ѝ я гледаше развълнувана 'Мать смотрела на нее в волнении'; Стоян вървеше свит 'Стоян шел сгорбившись' (букв. сгорбившийся, согнутый); Тя вече ме бе видяла и приближи сияещза 'Она уже увидела меня и подошла сияющая'.

Лексико-семантические типы глаголов, формирующих сказуемое основной предикации, разнообразны: это глаголы движения и позиции, конкретных целенаправленных действий, активного восприятия, речемыслительной деятельности. Но их объединяет одно: все они обозначают контролируемые действия.

Показательным является разрешение/запрет выступать в роли сказуемого данных конструкций у пар глаголов, противопоставленных по признаку «контролируемость». Так, глагол контролируемого действия слушам 'слушать’ (+ contr.) может быть сказуемым при ПО, а его аналог с семантикой неконтролируемого действия чувам 'слышать' (-contr.) - нет. То же демонстрируют пара гледам 'смотреть'/виждам 'видеть' :

Слушат го захласнати. - *Чуват го захласнати.

Той я гледа възхитен. - *Той я вижда възхитен.

Указанное «распределение ролей» - наиболее распространенный, но не единственный вариант первого ПО. Рассмотрим, как меняется семантика прототипической конструкции при замене одного из членов пары глаголом с противоположно отмеченным признаком. Для этого далее будем учитывать только ПО, выраженные отглагольными образованиями, т. е. причастиями.

Итак, можно ожидать существование еще трех вариантов: V (+ contr.) / Dep (+ contr.); V (- contr.) / Dep (+ contr.); V (- contr.) / Dep (- contr.).

б) Сказуемое, выраженное глаголом контролируемого действия, и ПО от глагола контролируемого действия, т. е. V (+ contr.) / Dep (+ contr.). Наш материал показывает, что любое причастие, образованное от глагола контролируемого действия, находясь в сфере действия агентивного сказуемого, имеет в конструкции с ПО ослабленную контролируемость и прочитывается как сопутствующий и одновременный с действием эпизодический статический признак (состояние):

${ }^{8}$ О контролируемости как семантическом признаке лексемы (но не ситуации), прежде всего в концепции Е. В. Падучевой, подробнее см. ИвАнОВА 2009а: 61-62, там же и литература. 
Тя вървеше навела глава 'Она шла, опустив (букв. опустившая) голову'.

Той стоеше все така изправен до прозореца 'Он все так же, застыв, стоял у окна’ (букв. стоял выпрямившийся у окна).

Примечательно, что депиктивные определения в этих случаях образуются преимущественно от глаголов с «нецеленаправленной» (неочевидной) контролируемостью, т. е. обозначающих автоматические, часто неосознанные действия человека: наведа се 'наклониться', изправя се 'выпрямиться', свия се 'сжаться', клекна 'присесть на корточки', усмихна се 'улыбнуться'. Эти действия часто производятся машинально, но, поскольку человек имеет возможность контролировать их протекание, в частности, способен их прекратить, они на этом основании входят в группу предикатов контролируемого действия. Их машинальный характер, однако, сказывается, когда они попадают в позицию ПО, подавляющую их «динамическую» семантику, ср. с неупотребительностью в качестве ПО причастий от глаголов с «сильной» контролируемостью, например, эталонных созидательных действий: Tu ме слушаш *готвещза обед; Влезе *подаващч ми писмо.

в) Сказуемое, выраженное глаголом неконтролируемого действия, и ПО от глагола контролируемого действия, т. е. V (- contr.) / Dep (+ contr.). Наши примеры на такое сочетание единичны, но они показывают, что в этом случае также наблюдается воздействие «формы» (т. е. давление семантики модели): сема «контролируемости» в причастии передается основному глаголу, обеспечивает его прочтение как глагола контролируемого действия: Tой спеше облечен 'Он спал одетым' - здесь спеше понимается не как состояние 'спать', а как контролируемое действие 'лечь спать'.

Для изучения действия параметра «контролируемость / неконтролируемость действия» в случаe V (- contr.) / Dep (+ contr.) требуется накопление дополнительных языковых данных.

В целом можно заключить, что признак (+ contr.) хотя бы у одного из участвующих в конструкциях (а)-(в) глаголов позволяет создавать и поддерживать типичную семантику данного построения 'контролируемое действие, производимое в определенном состоянии'.

г) Сказуемое, выраженное глаголом неконтролируемого действия, и ПО от глагола неконтролируемого действия, т. е. V (- contr.) / Dep (- contr.). В тех случаях, когда ни один член пары не является предикатом контролируемого действия, семантика конструкции меняется. Так, в каждом из примеров ниже описываются две ситуации, связанные между собой причинно-следственными отношениями, т. е. мотивирующее состояние привело к неконтролируемому действию:

Тя се изчерви смутена 'Она покраснела, смутившись' (Она смутилась и [в результате этого] покраснела).

Той се отдръпна отвратен 'Он отшатнулся в отвращении' (Он почувствовал отвращение и потому отшатнулся). 
Тя припадна ужжасена ‘(букв.) Она потеряла сознание, ужаснувшаяся’ (Она была так потрясена, что упала в обморок).

Селяните се опитаха да вдигнат крака на вола, но животното се стъписа изплашено (Й. Радичков) ‘...животное попятилось, испугавшись' (букв. испугавшееся).

Такие конструкции могут быть трансформированы в другие способы выражения причинно-следственных отношений, ср., кроме приведенных выше конструкций, предложные формы с причинным значением:

Тя се изчерви смутена. - От смущение тя се изчерви.

Тя припадна ужкасена. - Тя припадна от ужкас.

Той се отдръпна отвратен. - Той се отдръпна от отвращение.

Типичные конструкции с ПО (т. е. сказуемое от глагола контролируемого действия и ПО от неконтролируемого) не допускают никаких трансформаций, подобных приведенным выше развертываний в цепочку последовательно происходящих действий. Они предполагают полную одновременность предикаций (точнее, включенность промежутка времени, обозначенного депиктивом, во временной период основной предикации), ср.: Тя го погледна ужасена. 'Она посмотрела на него в ужасе'. = Тя го погледна и в погледа ѝ имаме ужас.

Заметим, что причинно-следственная связь выявляется иногда и при глаголе контролируемого действия (группа примеров А выше): Жената излезе засрамена 'Женщина вышла, застеснявшись'; Стоичковища изскочи уnлашена (Елин Пелин) 'Стоичковица выскочила, испугавшись'. Но в целом прототипическое значение не предполагает этой зависимости: состояние при типичном ПО лишь сопутствует действию, но не обуславливает его. Предложения с причинно-следственными отношениями подчеркивают именно значение обусловленности, и это имеет, в частности, синтаксические последствия - возможность передвижения определения в начальную позицию и его обособления: Отвратен, той отстъпи назад; Засрамена, жената излезе. Прототипические ПО таких трансформаций не допускают: Той се върна замислен 'Он вернулся в раздумьи'. - (?)Замислен, той се върна.

В рамках группы примеров (г), которые представляют соотнесенность V (- contr.) / Dep (- contr.), имеются несколько употреблений, которые содержат другую временную соотнесенность, представляя последовательные неконтролируемые реакции:

Усети развълнуван топлината на ръката ѝ (Г. Стоев) 'Он почувствовал с волнением теплоту ее руки', ср.: Усети топлината на ръката ѝ и се развълнува 'Он почувствовал теплоту ее руки и разволновался'; Гълъбът ужсасен го усети над себе си и падна съвсем ниско над водата; ср.: Усети го над себе си и се ужаси.

Построения с подобными временными связями (состояние возникло после действия в основной предикации) анализируются в синтаксической типологии как несколько иной тип вторичной предикации - как результативы, 
представляющие собой второстепенные предикаты в т. н. серийных конструкциях, ср. англ. He shot her dead 'Он застрелил ее намертво (букв. мертвую)'. При всей их близости к депиктивам они отличаются разной временной соотнесенностью с основным действием: депиктивы выражают фоновое действие или состояние, включенное во временные рамки основного действия, а результативы в серийных конструкциях передают последующий эффект основного действия: «состояние, выраженное результативом, достигается после временной рамки действия основного предиката» (НЕВскАя 2015: 87, см. литературу по данному вопросу там же).

Особый случай представляют предложения, в которых субъекты обозначают стихийные силы, природные явления: Дьрветата стърчаха измръзнали и почернели (Й. Радичков) 'Деревья стояли замерзшие и почерневшие', также: На сутринта небето светна синьо и чисто (А. Каралийчев); Планинският вятьр духаше вече доста свеж и силен; Слънцето заседна червено, кърваво и падна здрач (Елин Пелин).

В таких предложениях в качестве сказуемых используются глаголы-проявления, такие как святкам, духам, залязвам, тъмнея, изтичам, бликам и подобные (ИвАновА 2009b: 146-154). Такие предикаты «проявлений» имеют стертую динамическую семантику и приближены к связочным, и потому кажется более верным рассматривать их как образующие составное именное сказуемое. Сопоставление предложений Om сутринта денят вървеше дъжделив и Стария вървеше мрачен хорошо показывает разный «динамический» вес глаголов.

В переводе на русский язык, как уже видно из переводных соответствий выше, различия между центральной моделью и конструкцией с причинноследственными отношениями будут проявляться в выборе разных средств.

Для выражения актуального состояния служат наречия состояния (cмyщенно, потрясенно, изумленно), предложно-субстантивные сочетания со значением внутреннего состояния и внешнего проявления состояния: в гневе, с ульбкой, а также деепричастия (прежде всего настоящего времени гневаясь, смущуаясь, ульгбаясь):

Той я погледна смаян. - Он изумленно / в изумлении посмотрел на нее.

Тя вървеше усмихната. - Она шла, ульббаясь.

Причинно-следственные отношения находят выражение в предложных сочетаниях с причинной семантикой (из-за смущения, от смущения, от растерянности), в формах, указывающих на предшествующее мотивирующее действие (в основном деепричастия и причастия прошедшего времени разгневавшись, ульюнувшись, смутившись, испугавшись, испуганньй):

Тя се изчерви смутена. - От смущения она покраснела.

Тя се отдръпна уплашена. - Испугавшись, она отшатнулась.

Некоторые средства, например, предложное сочетание в ужасе, допускают как синхронное, так и причинное толкование, поэтому могут быть при- 
менены для перевода обоих типов конструкций, как (а), так и (г), ср.: Той я гледаше ужасен 'Он в ужасе (ужасаясь) смотрел на нее'; Той се отдръпна ужасен 'Он отшатнулся в ужасе (ужаснувшись)'.

\section{2. Конструкция с ПО к дополнению (с «объектным» ПО)}

Конструкция с объектным ПО синтаксически устроена иначе. Вторичнопредикативный элемент определяет не субъект, а объект, тем самым субъекту приписывается один предикативный признак, а объекту - другой: Поръсваме го още топьл с пудра захар 'Посыпаем его [пирог] сахарной пудрой еще теплым’. Более того, наиболее частотные в болгарском языке конструкции с объектным ПО при глаголе восприятия или перцептивного обнаружения (в примере далее), как мы упомянули выше (см. раздел 1), имеют усложненную, комплементативную связь: Той завари жена си и майка си прималели от страх... (И. Вазов) 'Он застал жену и мать охваченными страхом' (букв. совсем ослабевшими от страха), ср. в записи Св. Коевой: Завари [ги премалели] от страх (КоЕВА 2001: 65). Это иное синтаксическое устройство отражается и в принципиально разном семантическом взаимодействии элементов конструкции. Рассмотрим основные разновидности объектного ПО.

1. Семантическая разновидность конструкций с объектным ПО, наиболее приближенная к центральной модели субъектной ПО, сообщает о вре́менном признаке объекта, подвергающегося (подвергшегося) действию субъекта. В отличие от субъектных ПО, помимо объектной направленности синтаксической связи, отметим активность здесь в качестве ПО прилагательных с «параметрическими» качественными признаками. Это объясняется тем, что объект, характеризуемый предикативным определением, является чаще всего неличным, что понятным образом меняет и ограничивает набор определителей и максимально сокращает список причастных форм.

Кафето го пия студено 'Кофе я пью холодным'.

Поднасяме супата горещза 'Подаем суп горячим' .

Мога и чая да го пия горчив 'Я могу и чай пить несладким'.

Причастные формы, если они и употребляются, то, как правило, указывают на результирующее состояние: Сервираме го изстинало и поръсено c nудра захар 'Подаем его остывшим и посыпанным сахарной пудрой'; $C ъ x-$ ранете ги замразени '(букв.) Сохраните их [ягоды] замороженными'.

Реализация интересующего нас признака «contr.» соответствует центральной, прототипической модели: основной предикат обозначает контролируемое действие, второстепенный - эпизодическое, неустойчивое состояние.

В примерах типа Картофеното пюре го обичам солено 'Картофельное пюре я люблю соленым’ использован, на первый взгляд, глагол неконтролируемого действия обичам (таков он, например, в предложении: Обичам солено 'Я люблю соленое'), но в конструкции с ПО он предполагает более «активную» трактовку: Картофеното пюре обичам [да го ям] солено. 
Перевод на русский язык здесь не представляет затруднений, так как используются прилагательные и причастия в «депиктивных употреблениях» творительного падежа (САй 2011).

2. Другая семантико-синтаксическая разновидность объектного ПО является наиболее распространенной в болгарском языке. Она отражает ситуацию восприятия человеком другого объекта (чаще всего лица) и сообщает о состоянии последнего: Не съм я виждал усмихната 'Я не видел ее улыбающейся'; Помнеше я много разгневена (М. Радев) 'Он помнил ее очень разгневанной'.

В качестве сказуемого основной предикации используется класс перцептивных глаголов, отражающих ситуацию восприятия (усещзам 'ощущать', чувствам 'чувствовать', виждам 'видеть'), в том числе перцептивность случайного, нечаянного обнаружения (заварвам 'заставать', забелязвам 'замечать', откривам 'обнаруживать'), мысленного восприятия (Х застава пред очите [ми] 'Х встает перед моими глазами', представям си 'представлять себе') и «ретровосприятия» (спомням си 'вспоминать', помня 'помнить').

Как сказуемое могут быть употреблены единичные глаголы иной семантики, но чаще всего и они прочитываются как перцептивные: Не съм я срещзал (= не съм я виждал) никога обезпокоена и угрижена.

Большинство перцептивных глаголов обозначают неконтролируемые действия, а контролируемые представлены глаголами слабоактивной семантики: Представях си я унижена и разплакана 'Я представлял ее себе униженной и заплаканной'. Такой уход от контролируемости - это не грамматическое ограничение, оно объясняется характером ситуации восприятия: статические состояния объектов не столько сознательно наблюдаются, сколько неосознанно или пассивно воспринимаются. Активные глаголы восприятия в основной предикации могут быть употреблены, если ПО имеют семантику динамического действия (ПО - придаточные предложения, причастия активного залога, см. ниже).

Определительный компонент, как и при субъектном ПО, указывает на состояние объекта. Таким образом, оба участника (субъект восприятия и носитель состояния) в наиболее типичном случае выступают в роли экспериенцера. Одинаковая семантическая роль не является препятствием к построению предложения, так как эти роли распределяются по разным предикациям - основной и дополнительной.

ПО может выражаться причастной формой от глагола контролируемого действия, которая, в сфере действия перцептивного глагола, прочитывается как статическое состояние - актуальный результат прошедшего действия: Заварихме я седнала на пейката '(букв.) Мы застали ее севшей на скамейку’; Намерих я свита на леглото '(букв.) Я нашел ее сжавшейся в клубочек на кровати'.

Поскольку глаголы восприятия открывают объектную валентность, которую может занять не только предмет, но и ситуация, в функции ПО могут выступать придаточные изъяснительные предложения с союзами да и как 
(реже - иными), ср., например, Виждам я как стои и чака някого '(букв.) Я вижу ее, как стоит и ждет кого-то'; Не съм я чула да пее '(букв.) Я не слышала [ее], чтобы она пела'.

В большинстве случаев для перевода таких болгарских ПО на русский язык используются изъяснительные, временные или относительные предложения, но они не передают двойную синтаксическую соотнесенность депиктивных придаточных:

Следя я как шие. - Я слежу за ней, как [она] шьет/когда она шьет.

Наблюдавам го как размахва криле. - Я наблюдаю, как он размахивает крыльями.

Видях Мария да тича по перона. - Я увидел Марию, которая бежала по перрону.

Гораздо лучше для передачи депиктивного значения приспособлены русские причастия:

Заварих ги да се иелуват. - Я застал их иелующимися.

Доставяме иे огромно удоволствие да ме гледа молещ и унижен ... (К. Бачков) Ей доставляло огромное удовольствие смотреть на меня, просящего и униженного / видеть меня просящиим и униженным.

3. К числу ПО в традиционной лингвистике причисляются и предложения типа Bъзпитахме го почтителен 'Мы воспитали его почтительным'; Той ме е създал такъв 'Он создал меня таким'. Эти случаи с определением, выражающим результирующее состояние, выходящее за временные рамки основной предикации, относятся, скорее, ко вторичным результативным предикатам, о которых шла речь выше в разделе 4.1.

\section{5. Заключение}

Конструкции с предикативным определением интересны лингвистам, работающим в разных концепциях, как особый вид вторичной предикации: участнику основной предикации приписывается дополнительный признак, обычно временный, неустойчивый, причем время действия второстепенной предикации включено в период действия основной предикации. Одна из важных задач для понимания сути этой конструкции и вариантов ее реализации в разных языках заключается в выявлении прототипической модели.

В настоящей статье поиск прототипической модели связывается с признаком «контролируемость / неконтролируемость действия», содержащимся в семантике предиката как основной, так и второстепенной предикации. Прототипическая конструкция призвана целиком обеспечивать центральное значение построений с предикативным определением и быть максимально независимой от контекста. Такой результат обнаруживается лишь при следующей семантике компонентов субъектной депиктивной конструкции: в каче- 
стве основного предиката - глагол контролируемого действия, а в качестве предикативного определения - причастие от глагола неконтролируемого действия или неглагольный предикат состояния. Данное сочетание элементов проявляет наибольшую контекстуальную независимость для выражения основного для предложений с субъектным ПО значения 'действие лица, находящегося в том или ином состоянии' и - что важно для признания конструкции как прототипической - даже «корректирует» (заставляет переосмысливать) в нужном направлении семантику элементов, нечетко охарактеризованных по признаку «соntr.».

В то же время в конструкции, где обе глагольные формы образованы от предикатов неконтролируемого действия, выражаются причинно-следственные отношения. Разные семантические разновидности конструкций с субъектным предикативным определением (прототипическая и причинно-следственная) имеют разные переводные соответствия в русском языке.

Для предложений с объектным предикативным определением зафиксирована как близкая к прототипической модели разновидность, так и синтаксически усложненная, отражающая ситуацию восприятия, что диктует иное соотношение компонентов по признаку «contr.». В последнем случае «комплементативное» усложнение конструкции позволяет замещать позицию предикативного определения придаточными предложениями.

\section{Литература}

БъРКАЛОВА 2001 = БъРКАЛОВА П. Комбинаторен извод на конституентните правила в съвременния български език. В кн.: Съвременни лингвистични теории. Помагало по синтаксис. Пловдив, 2001. 14-37.

ГСБКЕ 1983 = ПопОв К. (ред.) Граматика на съвременния български книжовен език. Т. 3. Синтаксис. София, 1983.

ЗЕльдОвич 2005 = ЗЕЛьдович Г. М. Русское предикативное имя: согласованная форма, творительный падеж. Вопросы языкознания 2005/4: 21-38.

ИвАнОВА 2009а = ИвАнОВА Е. Ю. Признак «контролируемость действия» в исследовательском аппарате сопоставительного синтаксиса (на материале славянских языков). Acta Linguistica 2009/3: 61-70.

ИвАНОВА 2009b = ИвАНОВА Е. Ю. Сопоставительная болгарско-русская грамматика. Синтаксис. Т. 2. София, 2009.

КОЕВА 2001 = КоЕВА С. Малки изречения. В кн.: Съвременни лингвистични теории. Помагало по синтаксис. Пловдив, 2001. 61-67.

КУЗНЕЦОВА-РАХИЛИНА $2010=$ КУЗНЕЦОВА Ю. Л., РАХИЛИНА Е. В. Русские деПиктивЫ. В кН.: РАХИЛИНА Е. В. (ред.) Лингвистика конструкиий. Москва, 2010. 159-183.

КУЗНЕЦОВА-РАХИЛИНА 2014 = КУЗНЕЦОВА Ю. Л., РАХИЛИНА Е. В. ДепиктивЫ оказались удивительными. Acta Linguistica Petropolitana 2014/2: 180-218.

ЛАЗАРОВА 2001 = ЛАЗАРОВА М. Морфологични процедури за синтактична идентификация. В кн.: Съвременни лингвистични теории. Помагало по синтаксис. Пловдив, 2001. 3-13.

НЕВСКАЯ 2015 = НЕВСКАЯ И. А. Результативные второстепенные предикаты в тюркских языках. Сибирский филологический журнал 2015/2: 84-94. 
НикунЛАССи 1993 = НикунЛАССи А. Именительный или творительный? Синтаксические прилагательные при полнознаменательных глаголах в русском языке. Проблемы выбора падежа. Helsinki, 1993.

Пенчев 1993 = ПЕнчев Й. Български синтаксис. Управление и свързване. Пловдив, 1993.

ПЕНЧЕВ 1998 = ПЕНЧЕВ Й. СИНТаксис. В Кн.: БОЯДЖИЕВ Т., КУЦАРОВ И., ПЕНЧЕВ Й. Съвременен български език. Фонетика. Лексикология. Словообразуване. Морфология. Синтаксис. София, 1998. 498-655.

РАДЕВА 2005 = РАДЕВА П. Проблеми при идентификацията на чрезсказуемното определение в съвременния български език. В кн.: Научни изследвания в чест на проф. д-р Боян Байчев. Велико Търново, 2005. 433-440.

САй 2011 = САЙ С. С. Причастие. Русская корпусная грамматика. http://rusgram.ru.

ТЕСТЕЛЕЦ 2001 = ТЕСТЕЛЕЦ Я. Г. Введение в общий синтаксис. Москва, 2001.

FILIP $2001=$ FILIP H. The semantics of case in Russian secondary predication. Semantics and Linguistic Theory 11. Ithaca, 2001. 192-211.

Himmelmann-Schultze-Berndt 2005a = Himmelmann N. P., Schultze-Berndt E. F. (ed.) Secondary Predication and Adverbial Modification. The Typology of Depictives. Oxford, 2005.

Himmelmann-Schultze-Berndt 2005b = Himmelmann N. P., Schultze-Berndt E. F. Issues in the syntax and semantics of participant-oriented adjuncts. An introduction. In: Secondary Predication and Adverbial Modification. The Typology of Depictives. Oxford, 2005. 393-421.

Hinterhoelzl 2001 = Hinterhoelzl R. Semantic constraints on case assignment in secondary adjectival predicates in Russian. ZAS Papers in Linguistics 22. Berlin, 2001. 99-112.

Nichols 1978 = Nichols J. Secondary predicates. Proceedings of the Berkeley Linguistics Society 4 (1978): 114-127.

Schultze-Berndt-Himmelmann 2004 = Schultze-Berndt E., Himmelmann N. P. Depictive secondary predicates in crosslinguistic perspective. Linguistic Typology 8 (2004): 59-131.

VAn der Auwera-Malchukov 2005 = VAn der Auwera J., Malchukov A. A semantic map for depictive adjectival. In: Secondary Predication and Adverbial Modification. Linguistic Typology. Oxford, 2005. 393-421. 